بررسى تحليلى كاربرى اراضى (اراضى كشت آبى و بهنههاى آبى) در حوضه آبخيز درياجه اروميه با استفاده از تصاوير ماهواره لندست

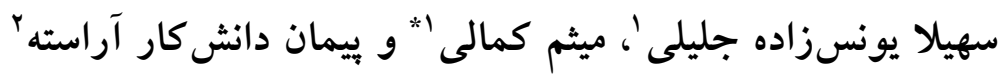

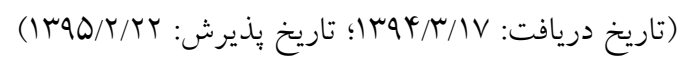

DOI: 10.18869/acadpub.jstnar.20.78.15

حكيده

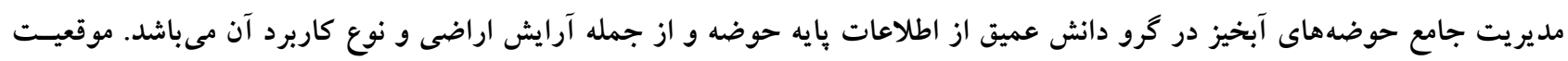

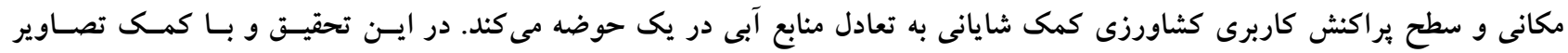

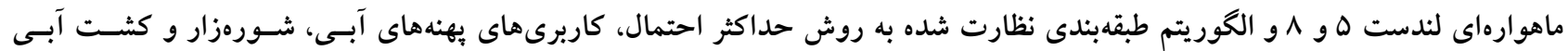

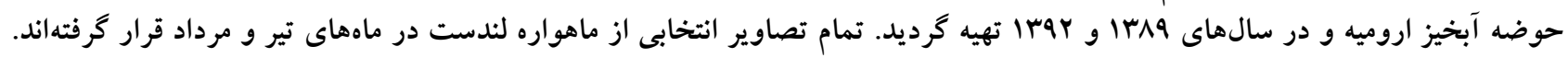

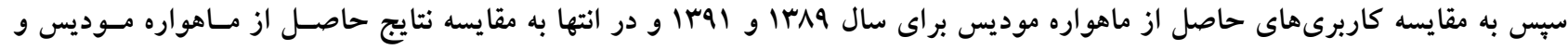

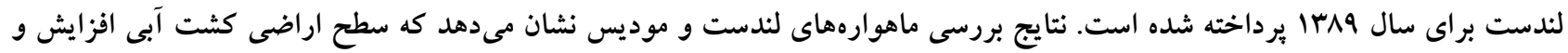

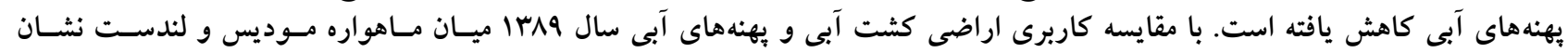

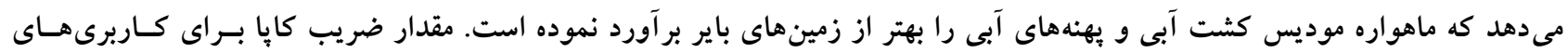

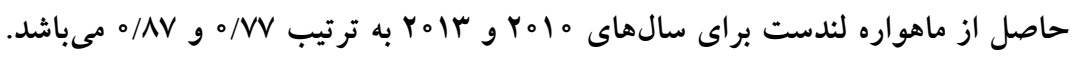

كلمات كليدى: كاربرى اراضى، حوضه آبخيز اروميه، اراضى كشت آبى، طبقهبندى كننده به روش حداكثر احتمال

ا. ا. مركز سنجش از دور، دانشگاه صنعتى شريف

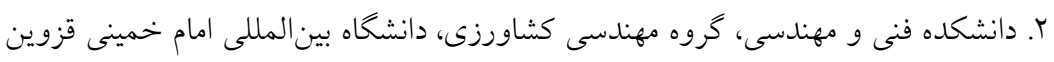

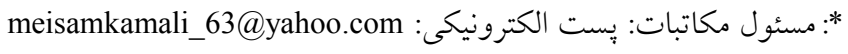




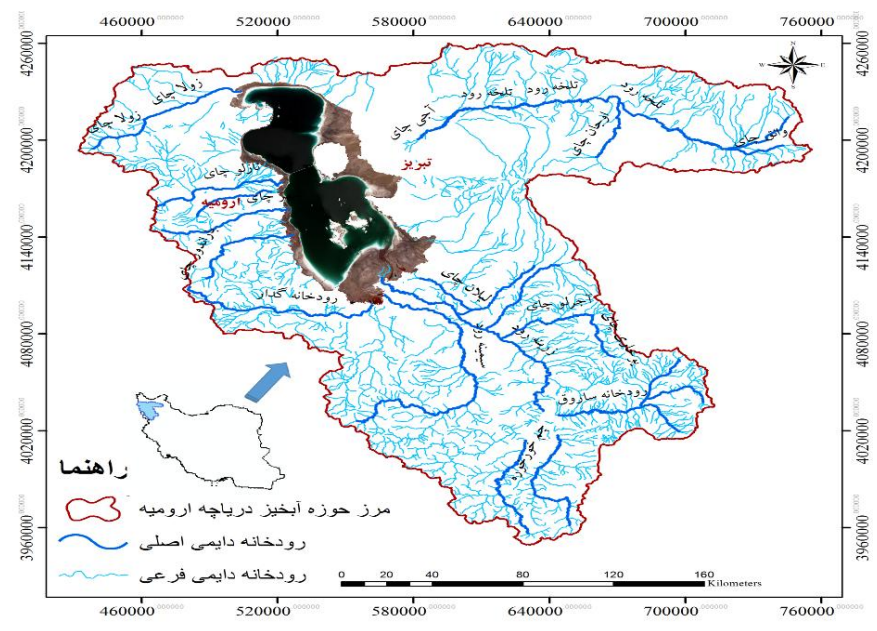

شكل ا. نقشه موقعيت و شماى كلى حوضه آبخيز درياجه اروميه

سنجش از دور بهدليل بوشش وسيع مكانى، قدرت تفكيك بـالا، مقدمه آرشيو زمانى غنى و هزينه كم مىتوانند اطلاعات مفيـدى توليـد

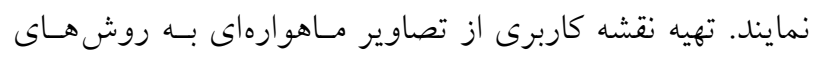

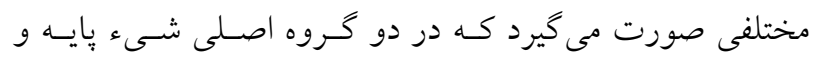

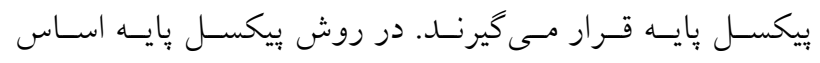

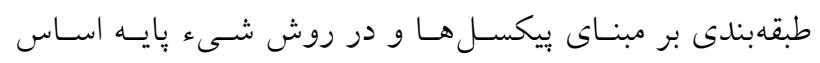

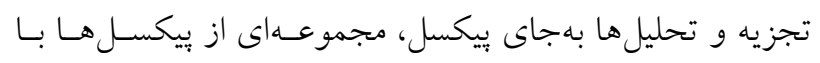
عنوان يديدههاى تصويرى است كه درنتيجه فر آيند قطعهبنــى حاصل مىشوند (IV) ). روش هاى ييكسل يايه در دو گروه عمده نظارت شده و نظارت نشده قرار مى گيرند. مرسـومتـرين شسيوه

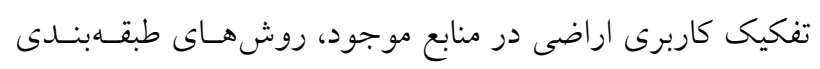
نظارت شده مىباشد ( l ( ). از بين روش هاى مختلف طبقهبنـدى كننده نظارت شده، روش حداكثر احتمال تـاكنون بـهـعــوان يـر

استفادهترين و دقيقترين روش شناخته شده است (Yo). مطالعـات زيـادى در مــورد اسـتخر اج كـاربرى اراضسى از تصاوير ماهوارهاى صورت گرفته است. سـتو و همكــاران (سب); در بِزوهشى به بررسى تغييرات كـاربرى اراضسى در دلتـاى رود ييـرل (واقـع در كشـور جـين) بـا اسـتفاده از تصـاوير مـاهواره Landsat TM جندزمانهاى، كوياى آن است كه وسعت مناطق شهرى در خلال سالهاى 1911 تا 1999 ميلادى بـيش از همبر٪ افـزايش داشـته است (YT). سعادت و همكــاران (YT); كـاربرى زمسين را بـراى حوضه آبخيز درياجه اروميه با مساحتى بالغ بر 0IAV9 كيلـومتر

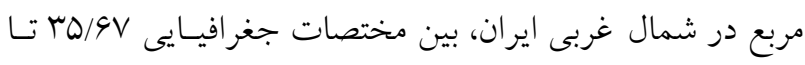

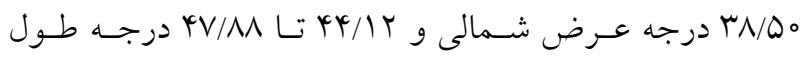

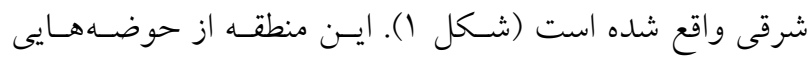

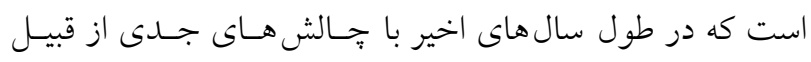

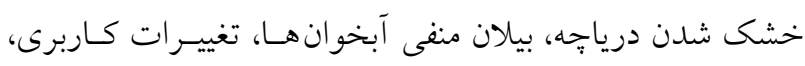

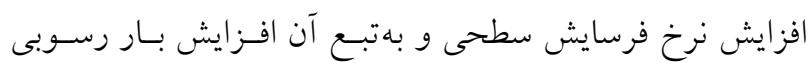

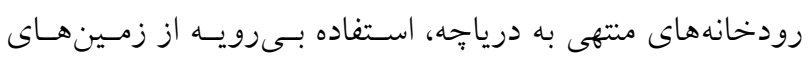

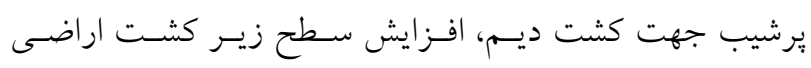

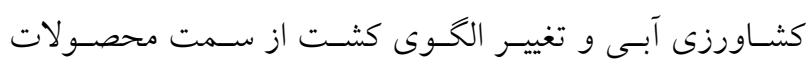

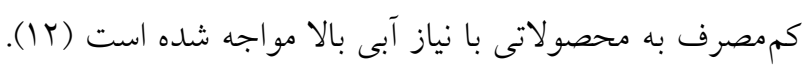

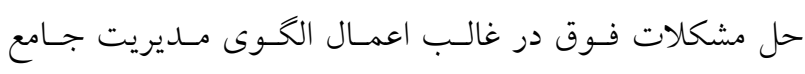

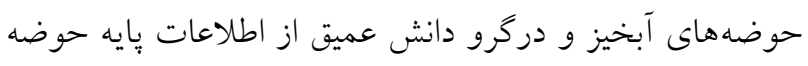

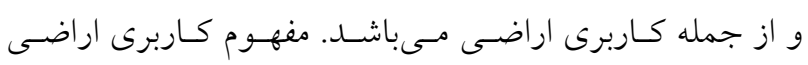

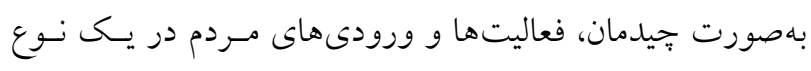

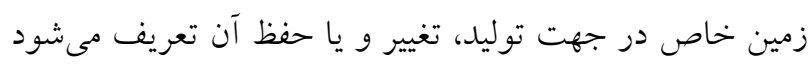

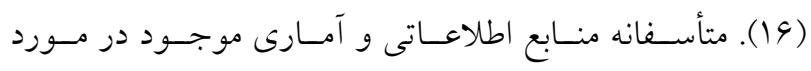

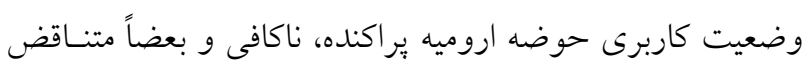

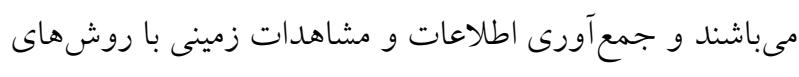

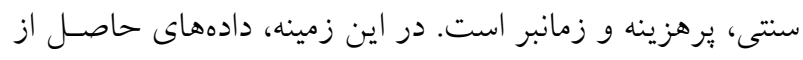


ماهو ارة نمودهاند. صحت كلى بهدست آمده براى طبقهبندى با الحسوريتم

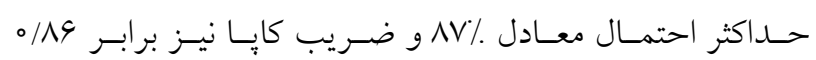

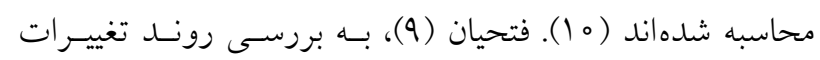

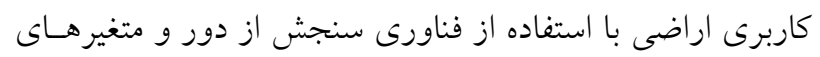

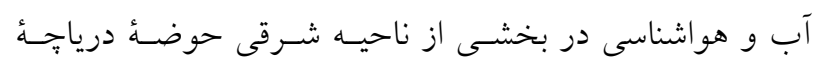

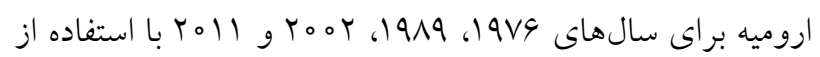
ماهو اره لندست يرداخت. نتايج تحقيقات نشـان داد كـه از ميـان

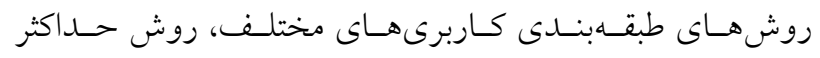

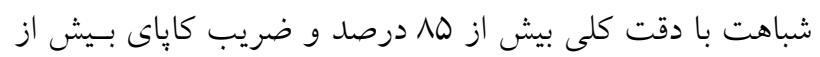

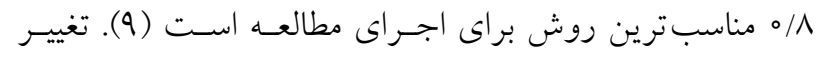

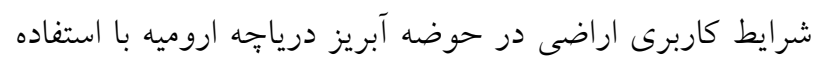

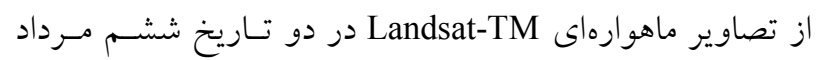

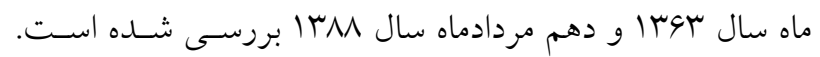

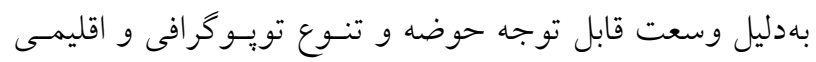

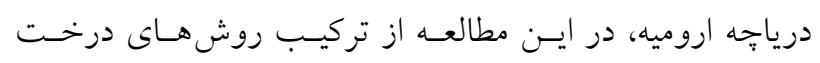

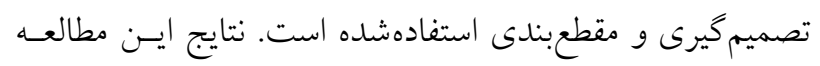

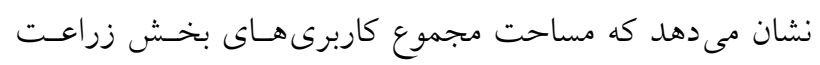

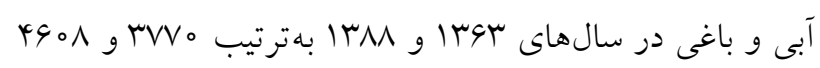

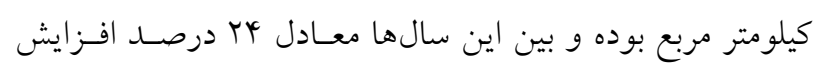

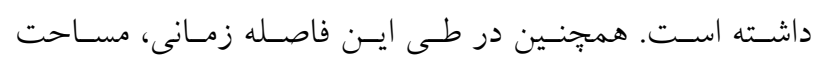

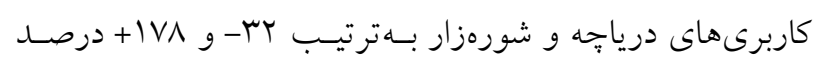

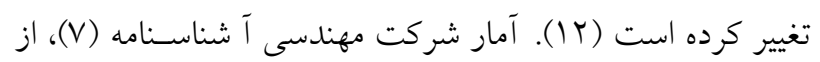

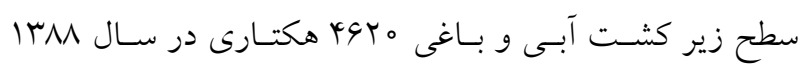

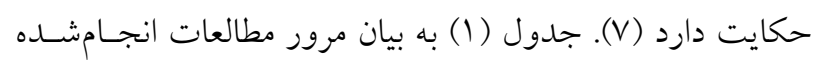

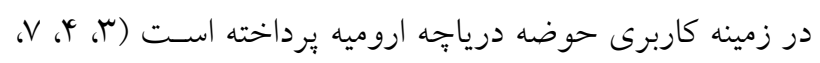

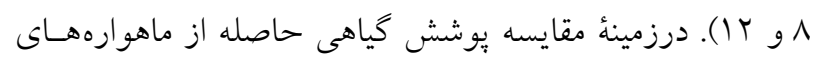

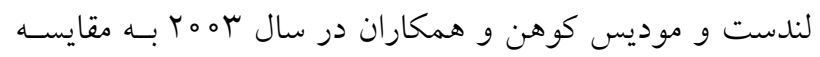

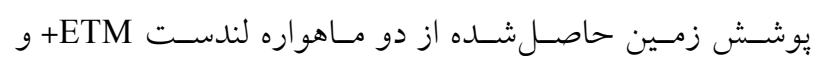

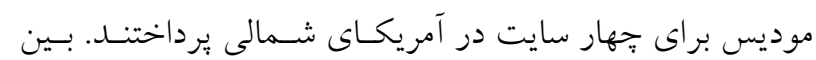

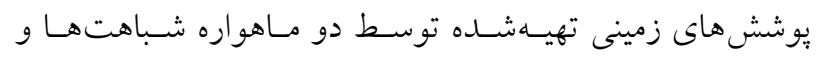

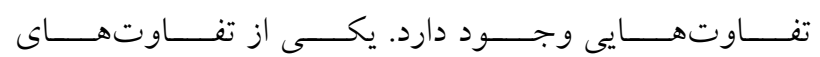

حوضه سد كلستان در ايران را بـا استفاده از اطلاعـات كمكى دي

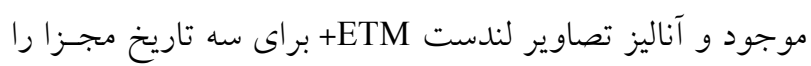

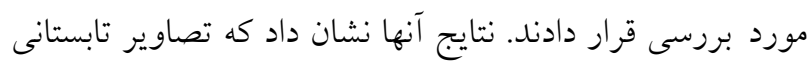

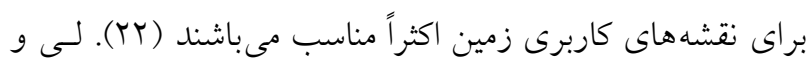

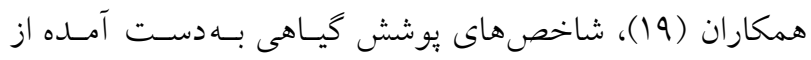

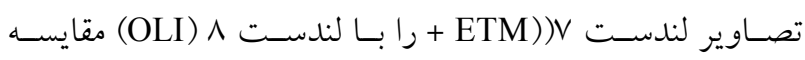

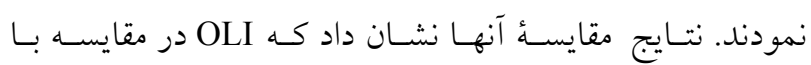

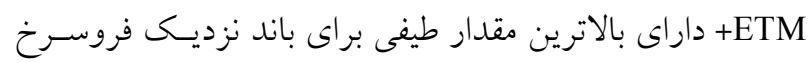

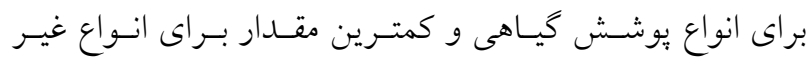

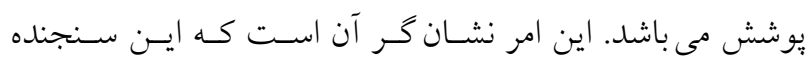

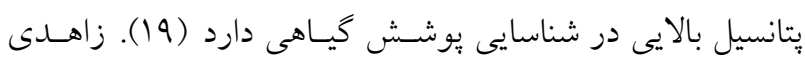

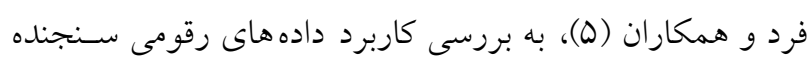

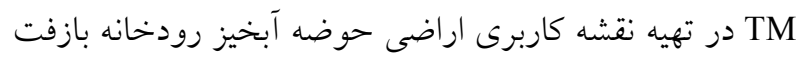

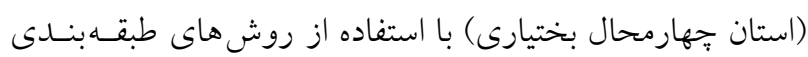
نظارت شده بيشترين شباهت، كمترين فاصله و متوازى السطوح

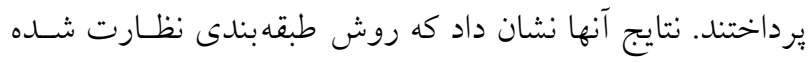

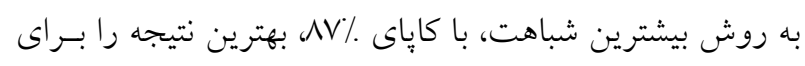

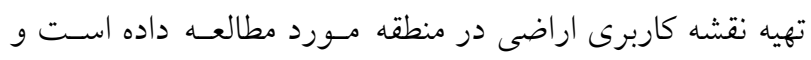

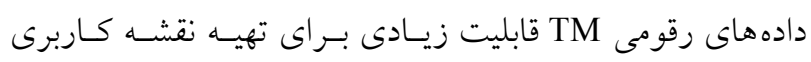
اراضى در منطقه مورد بررسى دارند (ه). احمد يور و همكـاران

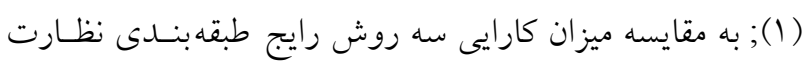

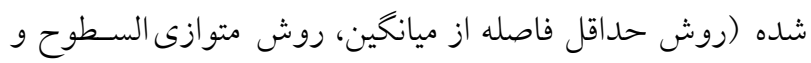

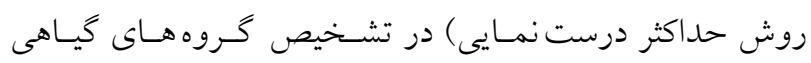

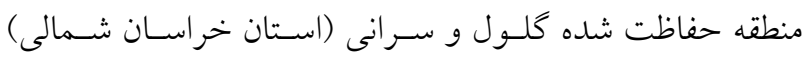

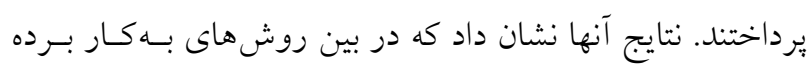

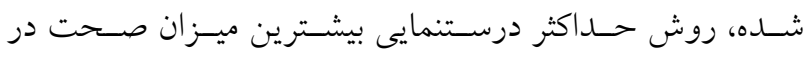

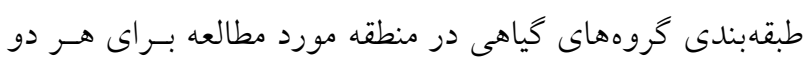

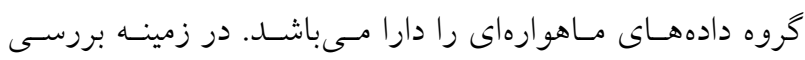

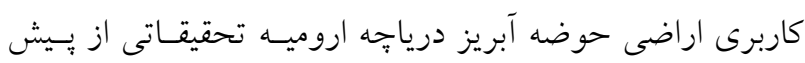

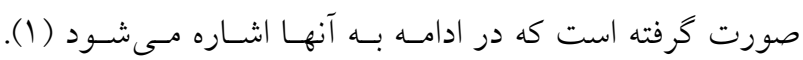

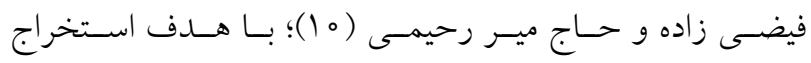
كاربرى هاى اراضى حاشسية شـرق درياجـــ اروميـه، از تصـاوير 
جدول ا. مرور مطالعات انجامشده درزمينه كاربرى حوضه آبريز درياجه اروميه

\begin{tabular}{|c|c|c|c|c|c|c|}
\hline 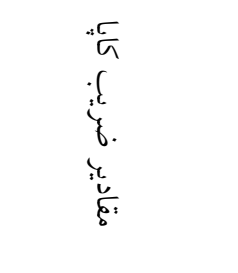 & $\begin{array}{l}0: \\
\vdots \\
i:\end{array}$ & 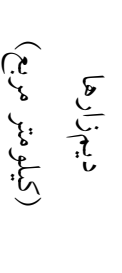 & 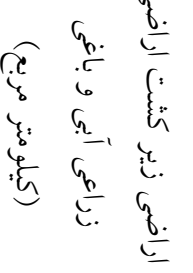 & 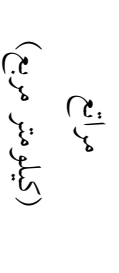 & $\begin{array}{l}\xi \\
i \\
\pi \\
\xi\end{array}$ & 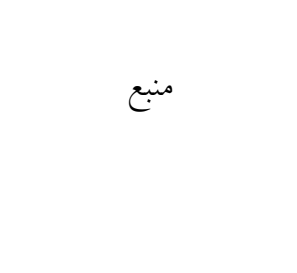 \\
\hline- & - & - & 1000 & - & $1 r \Delta \Delta$ & جامعلُ مهندسين مشاور \\
\hline- & - & - & بيش از ب000 & - & 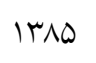 & ايران (r) \\
\hline$\% \wedge \mu / \Lambda$ & ماهو اره لندست سنجندة MSS & $11 \circ r_{0}$ & 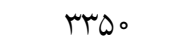 & $r 9100$ & iror & \multirow{4}{*}{ 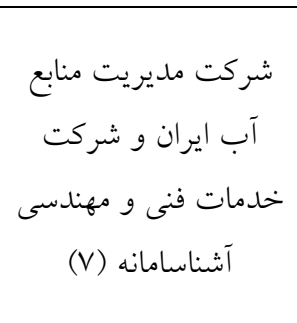 } \\
\hline$\% . \wedge 9 / 9$ & ماهو اره لندست سنجندة TM & 1०ґ^。 & r菂。 & TITOO & 11499 & \\
\hline$\% . \wedge \mathrm{V} / \mathrm{T}$ & ماهواره لندست ETM+ & lkmpo & $019 \circ$ & TQDQ。 & IMV & \\
\hline$\%$. $\mathrm{NV} / 9$ & ماهوارههاى اسُات و استر و & 10910 & kaY. & 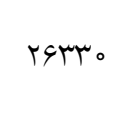 & IrMA & \\
\hline- & - & v991 & DYGY & - & 1499 & شركت مهندسين مشاور \\
\hline$\Delta F \% / r \Delta$ & ماهو اره لندست سنجنده TM و & qrVA & rquq & $199 \mathrm{V9}$ & IMV & خسرو شاهى و همكاران \\
\hline$\wedge \mathrm{V} \% / \mathrm{VV}$ & OLI ماهواره لندست سنجنده & $1199 \circ$ & rqTV & $190 \mathrm{M}$ & lrat & (广) \\
\hline سال ش1 نسبت به & ماهواره لندست سنجندة TM & svr。 & rVV。 & TrQYO & (rat & تحقيقات منابع آب ( I I ( ) \\
\hline
\end{tabular}

\section{مواد و روشها}

انجام اصلاحات قبل از طبقهبندى كردآورى دادهها و آمادهسازى تصاوير إنات طيقدين

براى انجام اين مطالعه تصاوير ماهوارهاى لندست هو و لندست

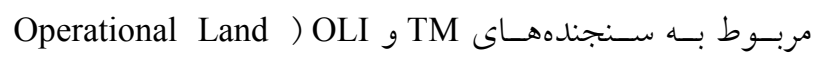

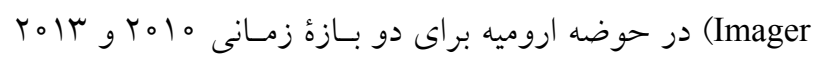

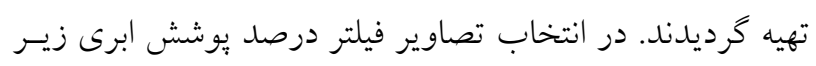

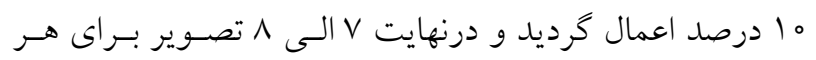

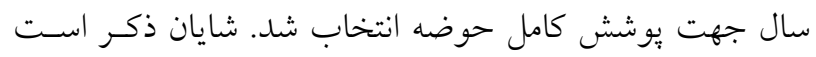

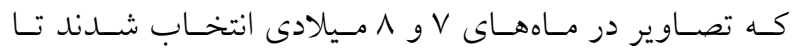

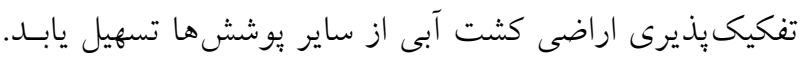

مشاهده شده قدرت تفكيك مكانى تصاوير موديس مىباشد كـه

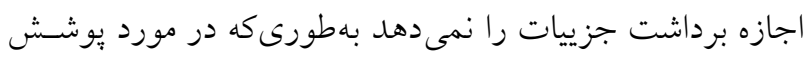

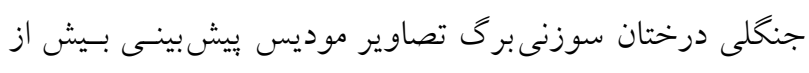

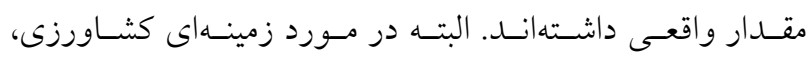

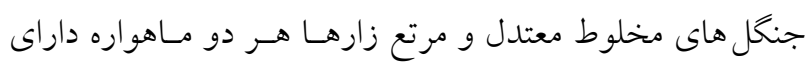

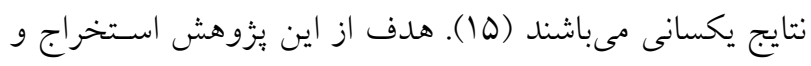

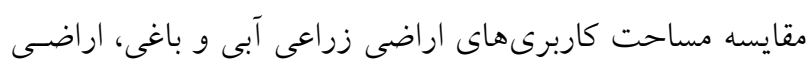

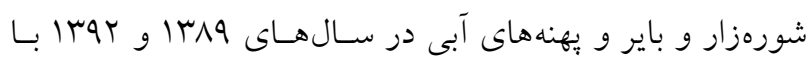

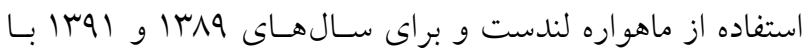
استفاده از ماهواره موديس مىباشد. در انتها نتايج حاصل از سال 911 ابراى دو ماهواره لندست و مـوديس مـورد مقايسـه قـرار

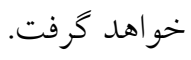




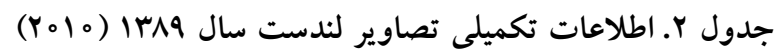

\begin{tabular}{|c|c|c|c|c|c|}
\hline سنسور & تاريخ اخذ & رديف و & وضوح تصوير & رديف & ماهواره \\
\hline Lه TM $\triangle$ (LPGS) & $r 010 / N / 11$ & $19 V-r Y$ & $\mu_{\circ}$ & 1 & \\
\hline L $\triangle \mathrm{TM} \diamond(\mathrm{LPGS})$ & $r 010 / N / 11$ & 19V-ro & $\mu_{\circ}$ & r & \\
\hline Lه TM $\triangle$ (LPGS) & $r 010 / \Lambda / 10$ & سוr-199 & $\mu_{\circ}$ & r & \\
\hline L $\triangle \mathrm{TM} \Delta(\mathrm{LPGS})$ & $r 0 \mid \circ / V / T$ & 191-r & $\mu_{\circ}$ & 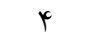 & لندست \\
\hline L๑ TM॰ (LPGS) & $r 010 / V / q$ & $199-\mu K$ & $\mu_{\circ}$ & 0 & $\mathrm{D} \mathrm{TM}$ \\
\hline L $\Delta \mathrm{TM} \Delta$ (LPGS) & $r 010 / V / r$ & $19 \Lambda-r y$ & $r_{\circ}$ & 9 & \\
\hline L@ TM® (LPGS) & $r 010 / V / 9$ & $199-r \Delta$ & r。 & v & \\
\hline Lه TM $₫$ (LPGS) & $r 010 / 1 / 19$ & 191-r山 & $\mu_{0}$ & $\wedge$ & \\
\hline
\end{tabular}

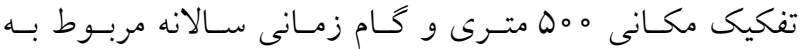

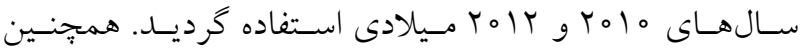
نقشههاى SRTM-DEM با قـدرت تفكيـى مكـانى هـ متـرى (برداشـتى از سـايت reverb.echo.nasa.gov) و نقشـه درصـد شيب تهيـه شـده براسـاس آن بـهنظـور تصـحيح تويـو گرافى برروى اطلاعات يوشش گياهى و كاربرى اراضى منطقه، مـورد استفاده قرار كرفت. خلاصه دادههاى ماهوارهاى اسـتفاده شــده در اين مطالعه در جداول ب و ب آورده شده است.

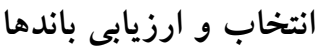

بهعلت رفتار طيفى مشابه بعضى از كلاسهـا در بخـشهـــي از طيف الكترومغناطيس، دخيـل كـردن بــش از ه بانـــ طيفـى در طبقهبندى منجر به كاهش صحت آن مىشود (4)؛ بنـابر اين لازم است تحليل همبستخى باندهاى مختلف سنجنده صورت گرفتـه و باندهاى با همبستخى بــالا از تحليـل كـاربرى حـذف شـوند.

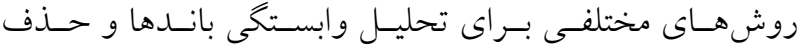
باندهاى اضافه وجود دارند. در اين مطالعه براى يـافتن تركيـبـ

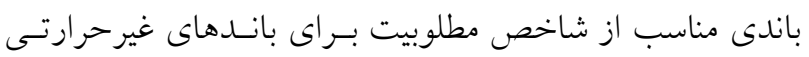
استفاده شده است. اين شاخص از تقسيم مجموع انحراف معيار سه باند بر مجموع ضرايب همبستخى دوبهدوى آنها محاسبهشده

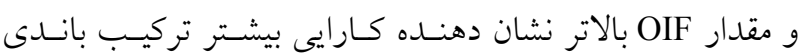

اين تصاوير يس از اعمال تصحيحات هندسى و راديومتريـك، موزاييك شده و در مرز حوضه اروميـه بــرش يافتنـد (Y (Y). در مرحله آخر عمليات بارزسازى خطى تصاوير جهت نمـايش و اسـتخراج بهتــر اطلاعـات صـورت يـذيرفت (YY). منظـور از

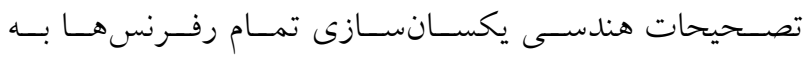

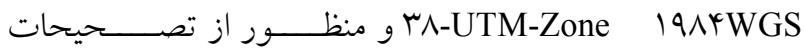
راديومتريك تبديل ارزش رقومى به اطلاعات طيفى و اصـلاح خطاى زاويهاى برداشت مسى باشـــ و بــا اسـتفاده از اطلاعــات موجود در فـراداده صـورت گرفتـه اسـت. منظـور از عمليـات بارزسازى خطى تصاوير افزايش كنتراسـت تصـاوير بـهـنظـور افـزايش تفـاوت موجـود بـين درجـات روشـنايى بيكسـلهـا بهمنظور روشنايى و تفكيك بهتر يديدههـا بـهـــورت بصـرى، عمليات خاصى صورت مى گيرد كه بهطـوركلى تحست عنـوان افزايش كنتراست تصاوير عنوان مىشـوند. عمليـاتى كـهـ بــراى افزايش كنتراست تصاوير اجــا مسىشـوند، در حقيقـت باعـث تغيير ارزش اطلاعاتى بيكسل ها شده، قدرت تفسـير بصـرى را افزايش مى دهنــــ و از اينــرو از يـكـ تصــوير جديـــ مسى تـوان اطلاعــات بيشـترى را اسـتخراج نمــود. در ايــن مطالعــهـ از نرمافزارهاى ENVI 5.1 و ArcGIS 10.1 اسـتفاده شــده اسـت.

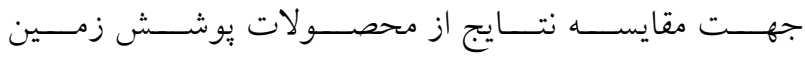
مربوط بـه حوضـه اروميـه بـا قـدرت 
جدول r. اطلاعات تكميلى تصاوير لندست سال rar Ir (ro)

\begin{tabular}{|c|c|c|c|c|c|}
\hline سنسور & تاريخ اخذ & رديف و & تصوير (m) & رديف & ماهواره \\
\hline OLI & $r \circ 1 r / v / 19$ & $19 \mathrm{~V}-\mathrm{rY}$ & $\mu_{0}$ & 1 & \\
\hline OLI & $r_{0} / r_{/ N} / r_{0}$ & $19 \mathrm{~V}-\mathrm{TO}_{\mathrm{O}}$ & $\mu_{0}$ & r & \\
\hline OLI & $r \circ \mid r / v / l \circ$ & سו-19N & $\mu_{0}$ & r & \\
\hline OLI & $r \circ \mid r / v / l \circ$ & $19 \Lambda-\mu K$ & $\mu_{0}$ & r & لندست \\
\hline OLI & $r_{0} \mid r / N / T V$ & | & r。 & 0 & \\
\hline OLI & $r \circ \mid r / \Lambda / 1 \Lambda$ & سז-199 & $\mu_{0}$ & 9 & \\
\hline OLI & $r_{0} / r / \Lambda / 1 \Lambda$ & $199-r k$ & $\mu_{0}$ & V & \\
\hline
\end{tabular}

در تفكيك عارضه هاى تصوير مسى باشـا. بـا محاسـبهُ شـاخص طبقهبندى به روش حداكثر احتمال

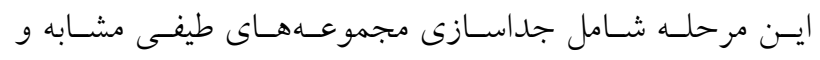

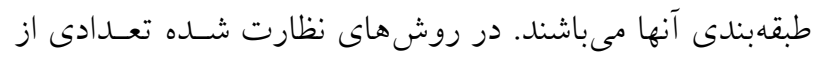

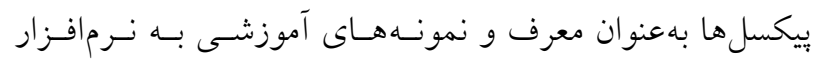

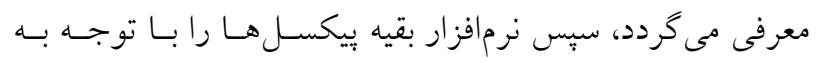
دستورالعمل خاصى نظير تابع حداكثر احتمال در مطالعه حاضـر

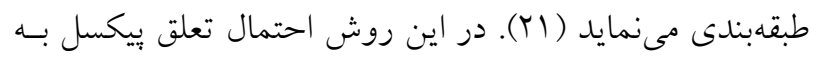

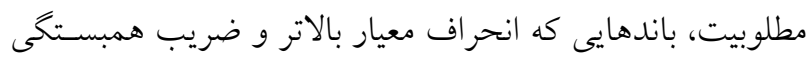

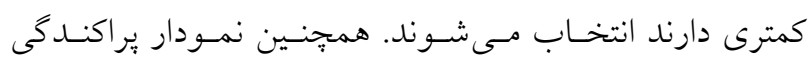
باندهاى مختلف تصاوير ترسيم و جهت انتخـاب تركيـب بهينـه

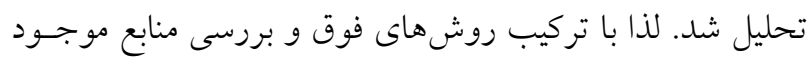
از تركيبهاى بهينه در تفكيك اراضى كشاورزى باندهاى مـورد استفاده در طبقهبندى مشخص گرديد. كلاسهاى مختلف توسط تابع احتمال محاسبه مىشود و توزيع

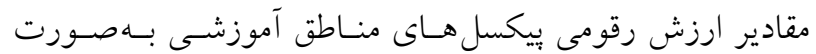
انتخاب نمونههاى تعليمى توزيع نرمال درنظـر گرفتسه مسى شـود. سـه مرحلـه كلسى روش حـــاكثر احتمـال شـامل محاسـبه بــردار ميـانخين، واريـانس و همبستخى براى كلاس ها در نمونهاى آموزشسى، لحساظ كـردن

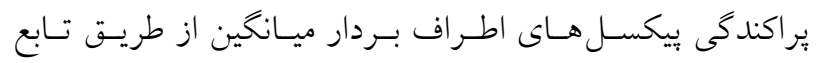
احتمالات و محاسبه احتمال تعلق هر بيكسل به كروههاى طيفى با استفاده از آزمون آمارى و درنظر كرفتن عامل شدت احتمـال، مىباشد (سا). كليه فر آيندها برروى تصاوير طيفى بــا بـالاترين شاخص مطلوبيت صورت گرفته است.

انجام اصلاحات يس از طبقهبندى

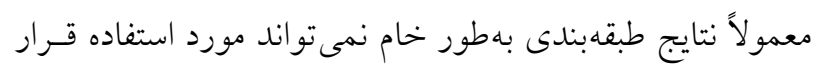

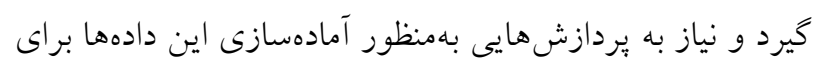

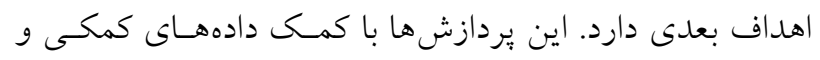

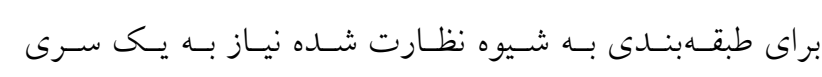

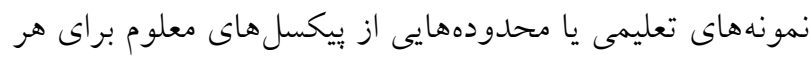

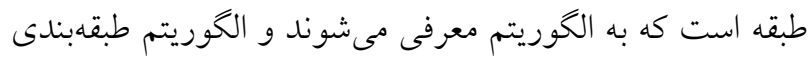

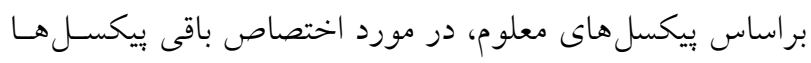

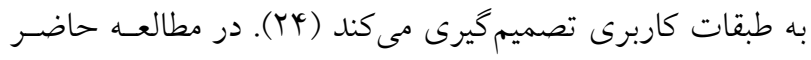

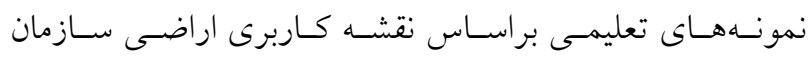

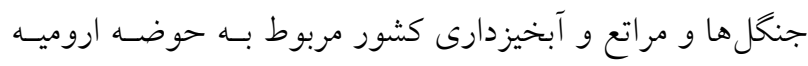

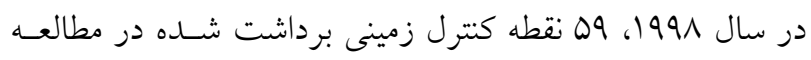

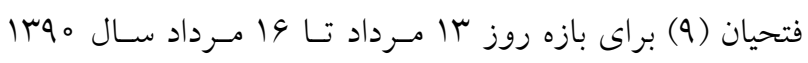

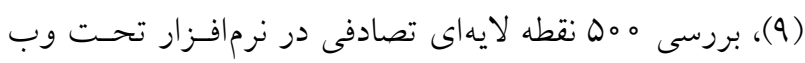
Google earth كارشناسى از تفسير بصرى تركيب رنخى مـادون قرمـز تصـاوير

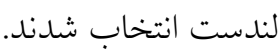


شيب بالاى \% 1 از كاربرى كشت آبى حسذف شــند. همجنــين با توجه به بررسى بصرى نواحى مرتفع و مزارع كشـت آبسى در نرمافزار تحت وب Google earth و با انتقال محدودههاى فـوق به نقشه DEM محسدودههـاى ارتفــاعى بـالاتر از مVO متـر از مناطق اختصاص دادهشده به كاربرى كشت آبسى اسـتخراج و در كلاس ساير كاربرىها قرار كرفت.

(Majority filter) اعمال فيلتر اكثريت در نقشههــاى موضـوعى حاصـل از طبقـهنـــى كـه مبتنى بــر

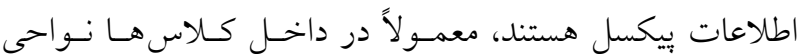
كوجهى وجود دارند؛ اين نواحى غالباً ناشسى از عوامـل خطـا و جزئيـات غيرمفيـا موجــود در دادههــا بـوده و مـانع مطلوبيـت نقشههاى طبقهبندى شده مىشوند (1) (1). براى رفع ايـن مشـكل

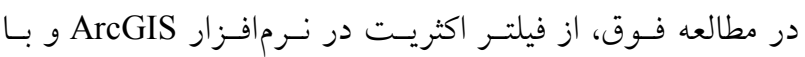

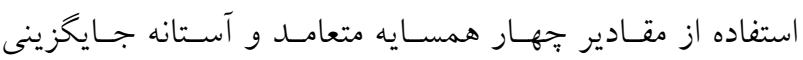
بهروش اكثريت استفاده كرديد. بدين ترتيـب اعمـال ايسن فيلتـر منجر به حذف بيكسل هاى منفرد و اصلاح طبقهبندى گرديد.

\section{تصحيحات تويو گر افى}

در اين مرحله بهدليل متفاوت بـودن زاويـهـ بيكسـلى خورشسيد، تأثير ارتفاعات و نقاط برشـيب در تغييـرات بازتـابش تصـاوير،

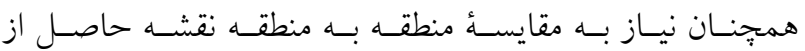
كالاسندى با لايه تركيب رنخى و ساير نقشههـاى يايـه وجــود دارد ( (T). براى مثال در اين مرحله تالابهاى حوضه كه توسط الكوريتم طبقهبندى به كلاس اراضى كشت آبى اختصـاص داده

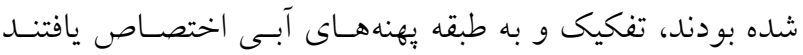

\section{آزمون صحت سنجى نتايج} بهدليل در اختيـار نداشـتن دادههـاى زمينـى، بـهـنــور بـرآورد صحت مناطق تخصيصسى بـهـ اراضسى كشـاورزى در سـالهـاى

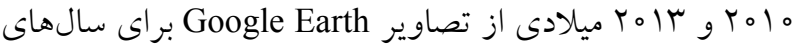

قوانين منطقى بوده و بهترتيب در ادامه تشريح شدهاند (Y).

\section{ارزيابى و ادغام كلاسها} بر مبناى اهداف مطالعه و نقشههاى موجود از كاربرى منطقه، در ابتدا و كلاس شامل اراضى شامل كشـت آبسى، يهنسهــاى آبسى، اراضى مرتعى، اراضى كشت ديم، اراضى باير و شورهزار و ساير

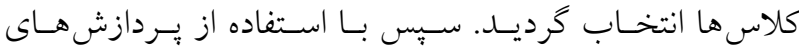
رقومى، يراكندگى كاسىها در فضاى دوبعـدى بانـدها بررسىى شد و كلاس هاى اراضى مرتعى و اراضى كشت ديسم بـه علـت

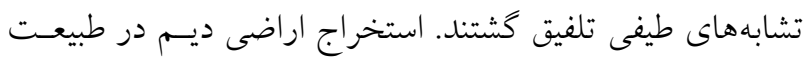
با استفاده از تصاوير مـاهوارهاى بــه دلايلسى نظيـر ارتفــاع قطع محصول يس از برداشت، استفاده از زمين بهعنوان جر اگاه، آيش

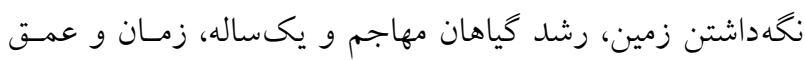
شخم و... بسيار مشكل مسىباشـــ و لـذا مجموعـه ايسن عوامـل وضعيتهاى بسيار متنوعى را ايجـاد مسىكنـــ كـهـ تفكيـى ايسن اراضى را از اراضى مرتعى فقير مشكل مسىسـازد (Y). همحِّنـين بهعلت استفاده از تصاوير تابستانه در مطالعه حاضـر و برداشـت محصولات ديمى در ماه مى (خردادماه)، تصـاوير فاقــ يوشـش ديمى بوده و شناسايى اراضى ديم را مشكل تر مىسازد.

\section{اصلاح با ماسك شيب و ارتفاع}

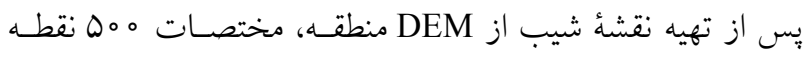
نمونهبردارى شده از Google earth كه داراى كاربرى مشـخص هستند برروى نقشه شيب منتقل و ارزش متناظر شيب اين نقاط

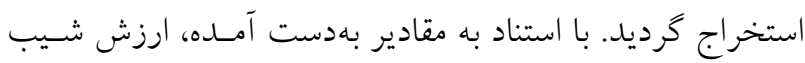
حداكثر ها درصد به كلاس اراضى كشت آبى تعلق يافت. براى

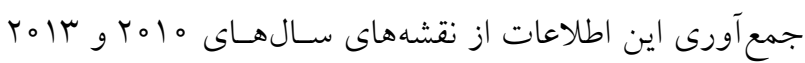

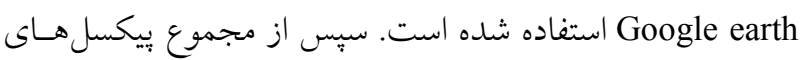
منطقه، به كل بيكسل هاى با شيب بالاى ه ا درصد ارزش صفر و به بيكسل هاى زير ه ا درصد عدد يك اختصـاص يافـت (YY). در مراحل بعلدى ماسك اصـلاحى حاصـل بـا نقشـــ حاصـل از طبقه بندى ادغام و كل بيكسل هاى حاصل بــارزش صـفر يـا بـاــا 


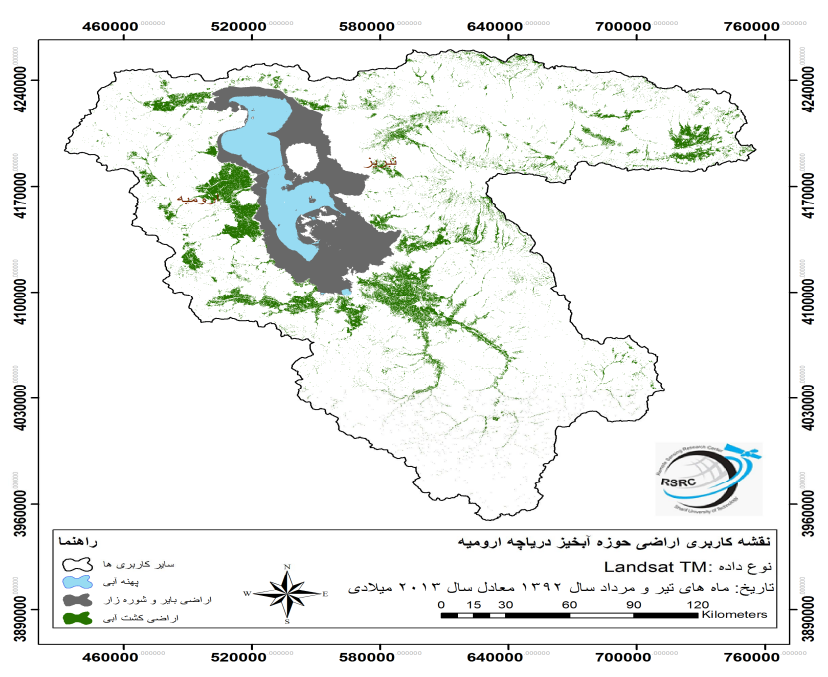

شكل r. نقشه براكنش اراضى كشت آبى، بهنه هاى آبى و اراضى

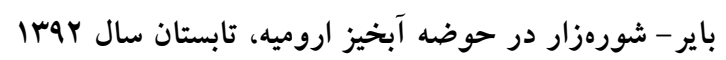

نتايج با بررسى تو أم شاخص مطلوبيت، تفسير منحنسىهـاى انعكـاس

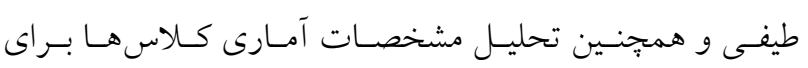

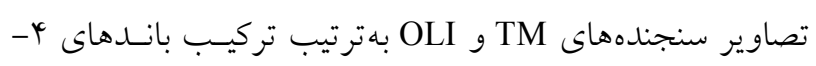

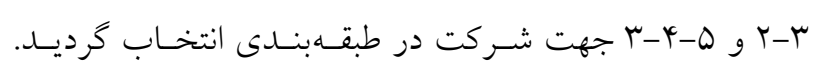

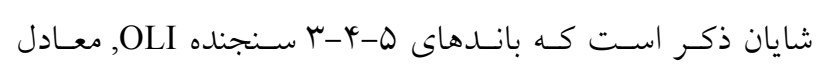
باندهاى ץ-Y-Y از سنجنده TM است. بـادليل هميوشانى طيفى

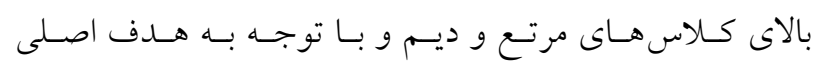
يزوهش كه تفكيك اراضى زراعسى مسى باشــ، سـاير كـلاس هــا ادغام كشته و درنهايت طبقه بندى براساس جهار كاس اراضسى كشت آبسى، يهنسههــاى آبسى، اراضسى بـاير و شـورهزار و سـاير

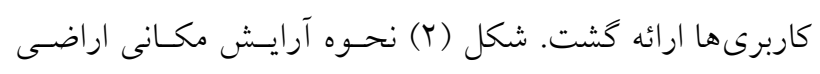
كشاورزى آبى و باغى، يهنههاى آبى و اراضسى بـاير و شـورهزار

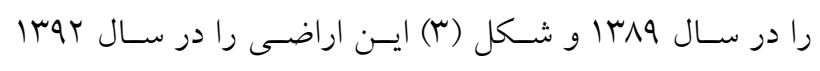
نشان مى دهل. همانطور كه در شـكل مشـخص اسـت، اراضسى

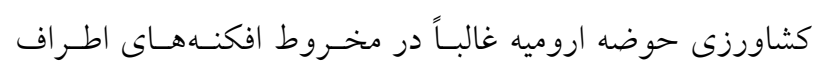
درياجِه كسترده شدهاند.

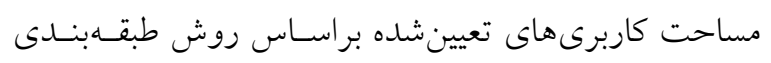
حداكثر احتمال در جدول (†) بيان شده است. اين جدول نشئان

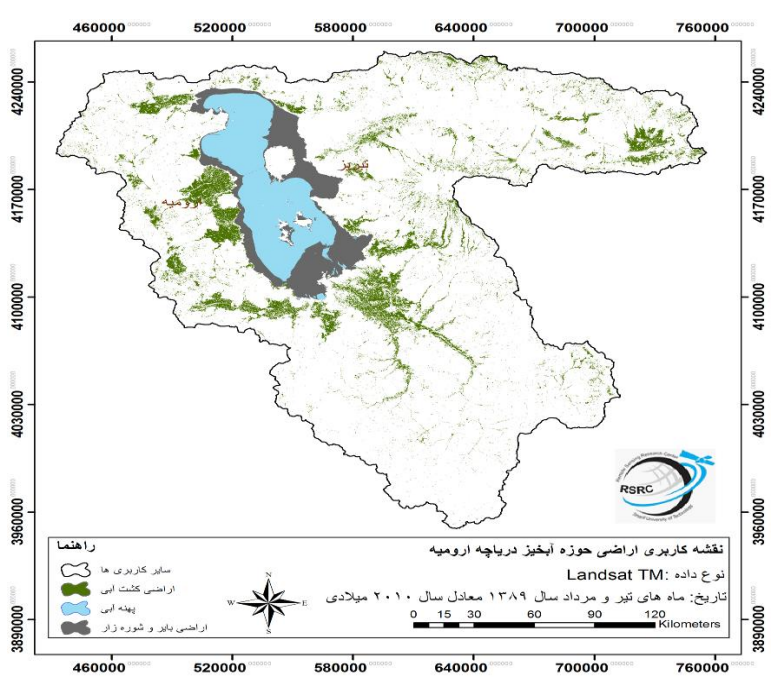

شكل Y. نقشه ير اكنش اراضى كشت آبى، بهنههاى آبى و اراضى باير - شورهزار در حوضه آبخيز اروميه، تابستان سال 9هـ1

مختلف استفاده گرديل. بههمين صورت 911 نقطه براى هر يك از سالها در نرمافزار كو گل بـا كـاربرىهـاى مختلـف (اراضسى زراعى آبى و باغى، اراضى باير و شور زار، يهنه هاى آبى و ساير

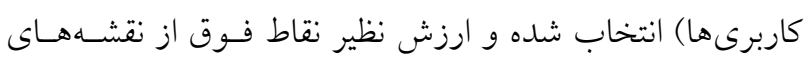

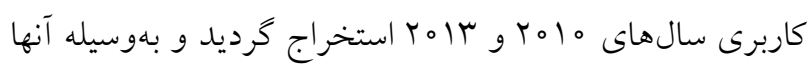
ماتريس خطا، ضريب خطـا و صسحت كلى بــراى هـر يــى از سالها تعيين كرديد.

مقايسه نتايج بهدست آمده با محصولات بوشث زمين سالانه MODIS

بهمنظور مقايسه نتايج بهدست آمـله، از محصـولات يوشـش زمسين سالانه (MCD12Q1) MODIS با فرمت HDF استفاده گرديد. ايسن IV تصاوير براساس طبقهبنـدى نـوع يـى (Type 1(IGBP) داراى كلاس بوشش مىباشند. در اين سيستم طبقـهبنـدى اراضسى كشـت

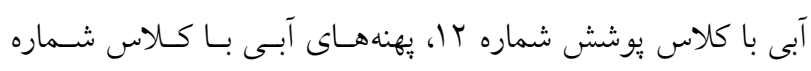
صـفر و اراضسى شـورهزار و بـاير بـا كـلاس شـماره 19 مشـخص

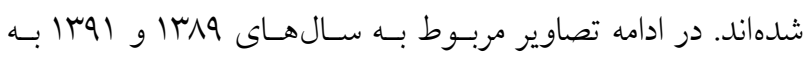

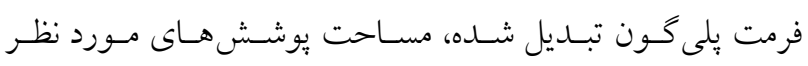
محاسبه و با اعداد بهدست آملده از مطالعه حاضر مقايسه گرديد. 
جدول \&. مساحت كلاسهاى مختلف بوشش زمين (كيلومتر مربع) برغرفته ماهواره لندست در سالهاى

\begin{tabular}{|c|c|c|c|}
\hline 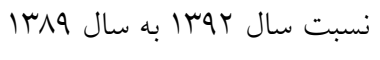 & $1 \% q r$ & $1 r \wedge q$ & 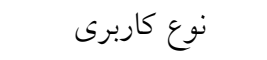 \\
\hline $1 / 9$ & gry & $\varphi \circ \wedge r$ & اراضى كشت آبى \\
\hline $0 / 9$ & $19 V 9$ & (9) & يهنهاى آبى \\
\hline $1 / 00$ & MVAG & TEYV & اراضى باير و شورهزار \\
\hline
\end{tabular}

جدول ه. ماتريس خطا و صحت طبقهبندى سال

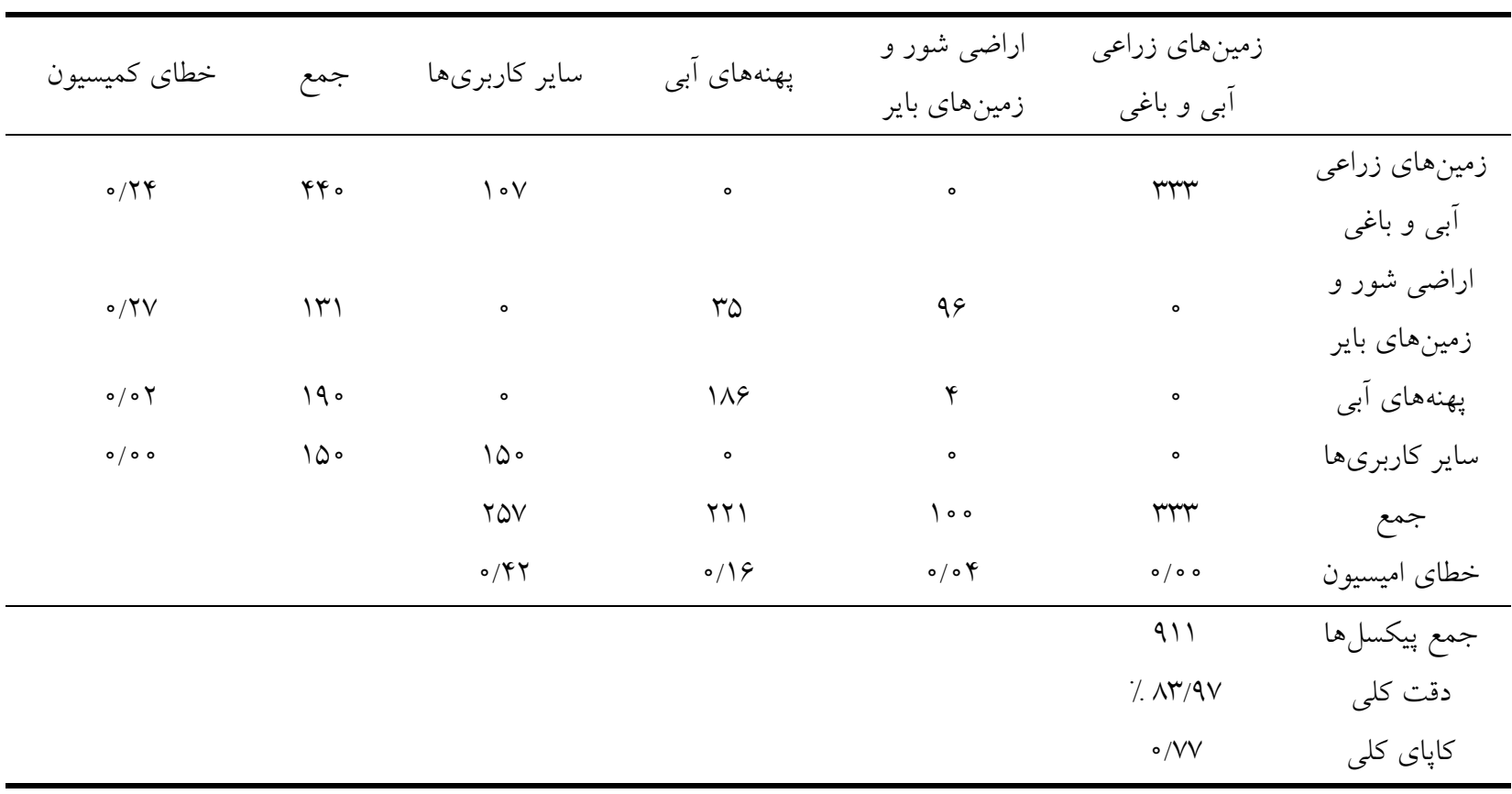

سـالهـاى

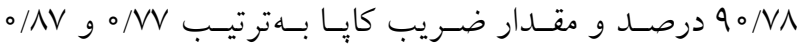
مىباشد. شكل با نقشه يوشش زمسين MODIS را بــراى شـماره

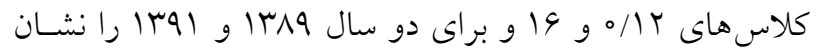
مىدهد. براسـاس شـكل (Y) سـطح درياجـه كـاهش و اراضسى كشاورزى بهويزّه در نـواحى جنـوبى و جنسوب غربسى درياجـهـ

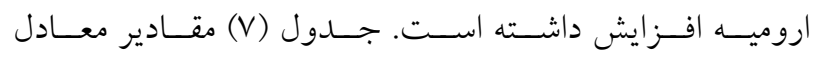
كـاربرىهـاى فـوق را در محصـول بوشـش زمسين از سـنجنده نشان مىدهــد. براسـاس ايسن جـدول نسـبت اراضسى

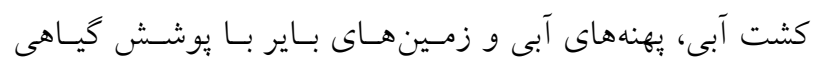

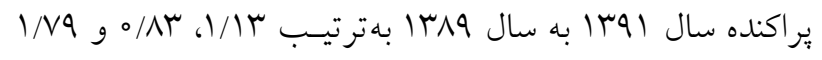
مىباشد. نسبت كاربرى كشت آبى، يهنهاى آبسى و زمسينهـاى
مى دهد كه مساحت اراضى كشـت آبسى در سـال و1با معـادل

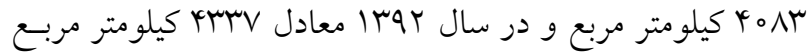
است و نسبت مساحت اراضى كشت آبى سـال rوبا بـه سـال

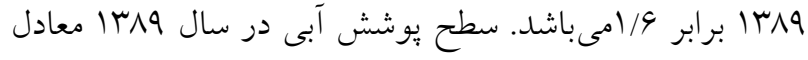
צاسM كيلومتر مربع و در سال بوس ا معادل 19V9 كيلومتر مربـع

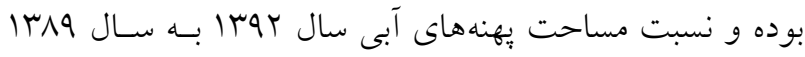
برابر 9/ه مىباشد. براساس همين جدول نسبت مساحت اراضى

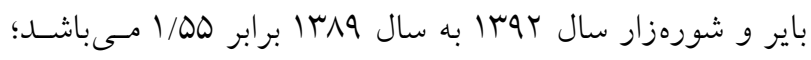

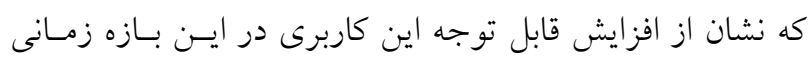
دارد. جداول(ه) و (9) مـاتريس خطـاى كـاربرى هـاى اراضسى

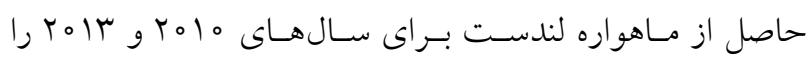
نشان مى دهند. با توجه به اين جداول مقدار صحت كلى بـراى 
جدول 9. ماتريس خطا و صحت طبقهبندى سال Y Yr ا (ro|r)

\begin{tabular}{|c|c|c|c|c|c|c|}
\hline خطاى كميسيون & جمع & كاربرى ساير & يهنه آبى & زارمينى شور و & زمينهاى زراعح & \\
\hline$\circ / 0091$ & FYo & TS & $\circ$ & $\circ$ & YIY & زمينهاى زراعى آبى و باغى \\
\hline$\circ / 4900$ & roo & $\circ$ & $\Delta \wedge$ & let & $\circ$ & اراضى شور و زمينهاى باير \\
\hline$\circ / 0000$ & $|r|$ & $\circ$ & $|r|$ & $\circ$ & $\circ$ & يهنه هاى آبى \\
\hline \multirow[t]{6}{*}{$\circ / 0 \circ \circ \circ$} & 100 & 100 & $\circ$ & $\circ$ & $\circ$ & ساير كاربرىها \\
\hline & & IVG & 189 & lkt & yit & جمع \\
\hline & & $\circ / 14 \wedge$ & OMTY & $\circ / 0 \circ \circ$ & $\circ / 0 \circ \circ$ & خطاى اميسيون \\
\hline & & & & & 911 & جمع بيكسل ها \\
\hline & & & & & $\% 9 \circ / \mathrm{VA}$ & دقت كلى \\
\hline & & & & & ०/AV & كإِاى كلى \\
\hline
\end{tabular}

جدول V. مساحت و تغيير مساحت كاربرىهاى مورد مطالعه در حوضه آبخيز اروميه، سالهاى

\begin{tabular}{|c|c|c|c|c|}
\hline نسبت سال |qس| به سال 91|| & $|r q|$ & $1 \% \wedge 9$ & نوع كاربرى در مطالعه حاضر & نوع يوشش در محصول موديس \\
\hline $1 / 1 \mu$ & $\Delta \wedge G Y$ & 0199 & اراضى كشت آبى & زمين هاى زراعى \\
\hline 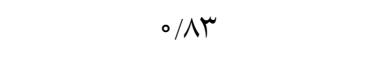 & $M D_{0}$ & $\longleftrightarrow \wedge \circ \psi^{+}$ & يهنهاى آبى & يهنهای آبى \\
\hline $1 / 19$ & סמוץ & 1190 & اراضى باير و شورهزار & زمينهاى باير يا داراى يوشش \\
\hline
\end{tabular}
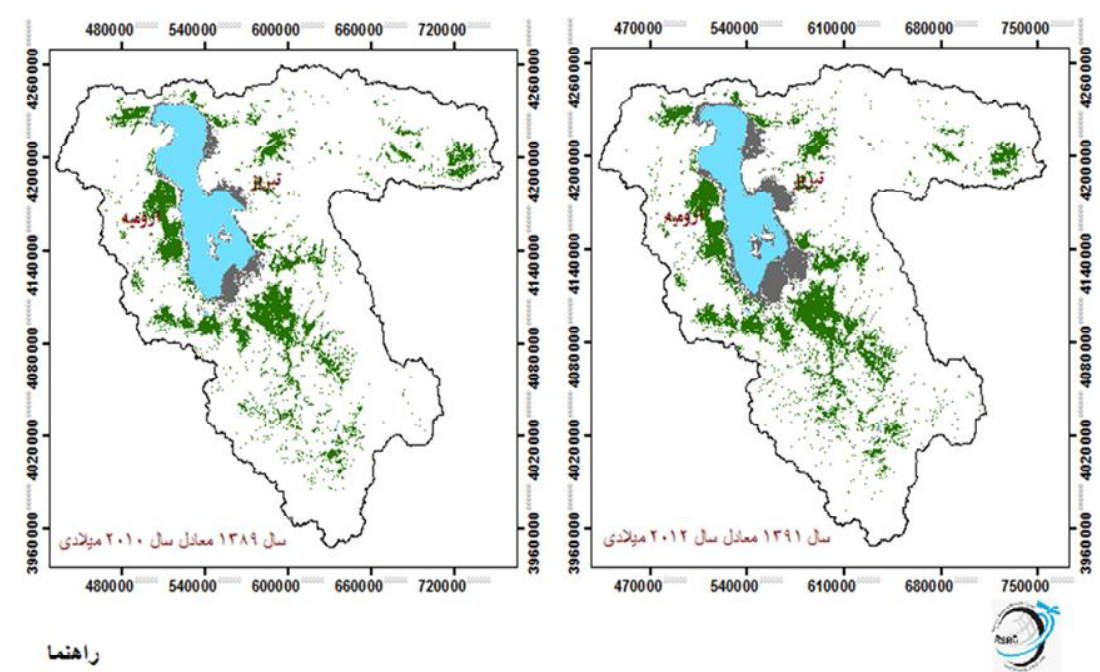

راهنسا

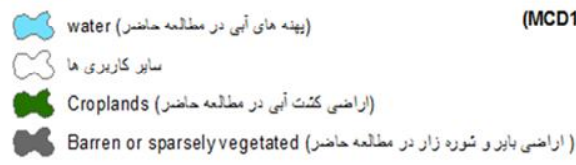

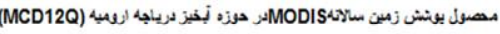

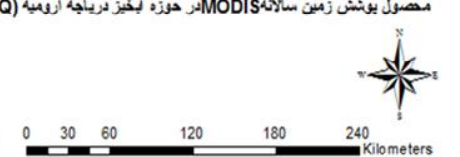

شكل f. نحوه يراكنش كاربرىهاى مورد مطالعه در محصول يوشش زمين MODIS در سالهاى 
كه همانند ماهواره لندست نشان از افزايش مساحت زمسينهـاى

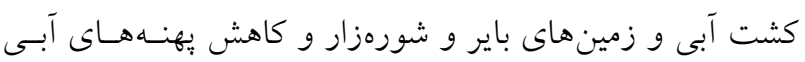

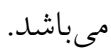

تصاوير مـاهواره لندسـت و مـوديس در سـال 91/ انشـان

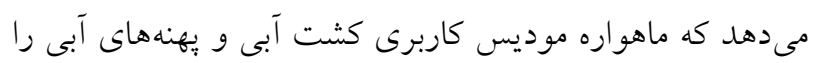
با دقت بهترى نسبت به ساير كاربرىها نشان مىدهــــ همجينـان

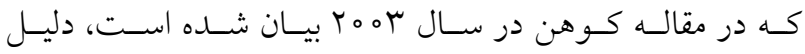
اختلافات موجود در نتايج استخراج شده از مـاهواره لندسـت و و

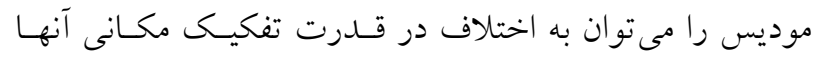
نسبت داد(1) ). درزمينـهُ زمسين هـاى بـاير و شـورمزار تصـاوير موديس داراى اختلاف قابل توجهى با تصوير لندست مىباشـــ. دلايل اختلاف نتايج ميان ماهواره لندست و موديس رامىتسوان عدم قدرت تفكيكى مكانى يكسان ميـان ايـن تصـاوير دانسـت. علاوه بر تفاوت قــدرت تفكيكى مكـانى، اخستلاف حاصـل بــه ماهيت سالانه بودن محصول MODIS و روزانه بودن محصـول لندست برمى خـردد. نقشـهــاى كـاربرى روزانسه تنهـا قـادر بـهـ

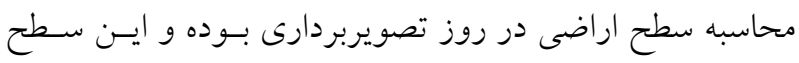

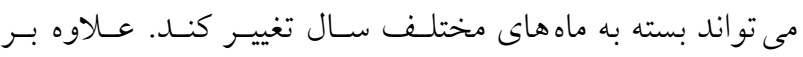

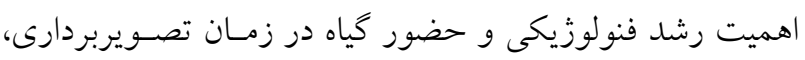

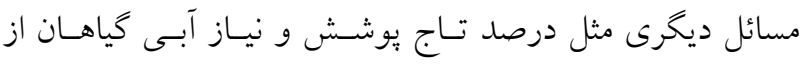

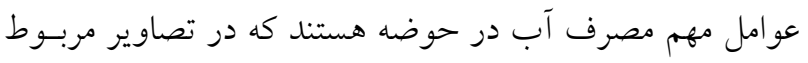
به يكى روز خاص درنظر گرفته نمىشوند.

\section{سباسكزارى}

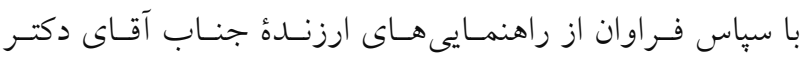

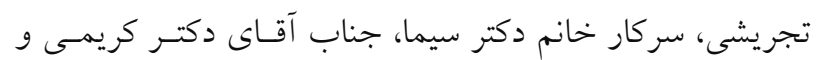

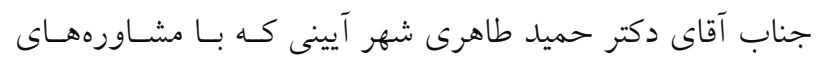

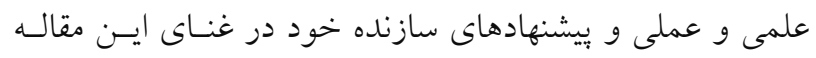
نقش بسز ايى داشتند.

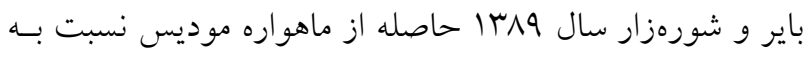

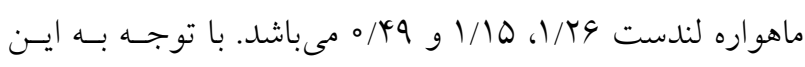

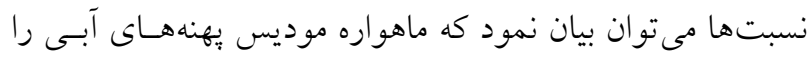

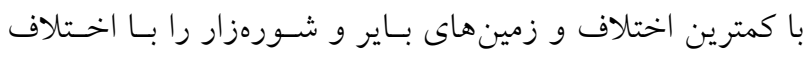
قابل توجهى بيشبينى نموده است.

\section{بحث و نتيجه گيرى}

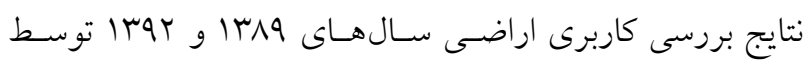

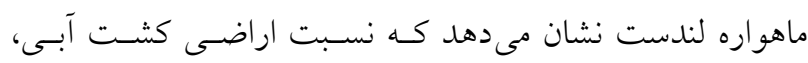

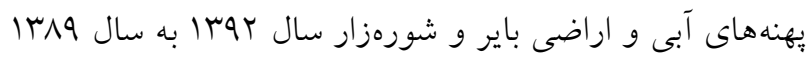

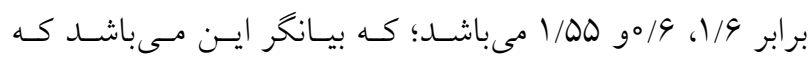

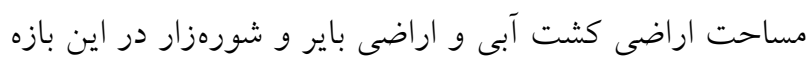

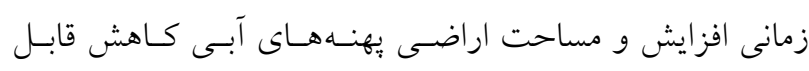

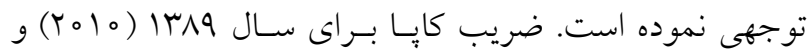

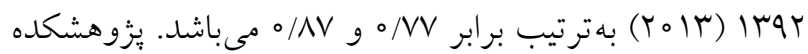

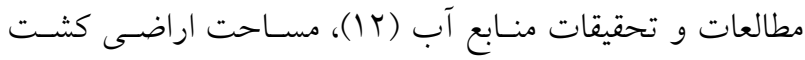

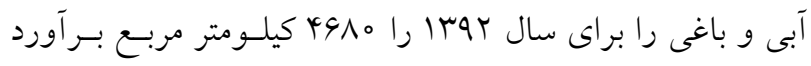

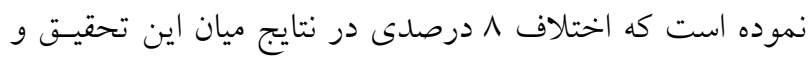

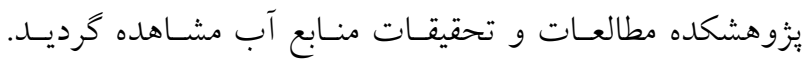

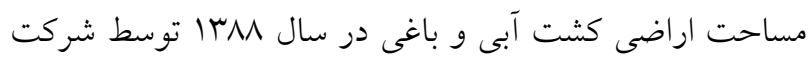

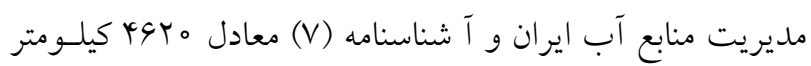

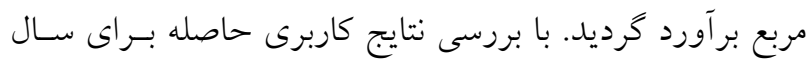

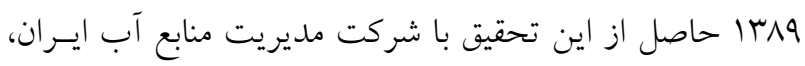

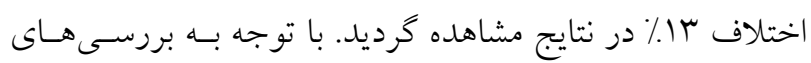

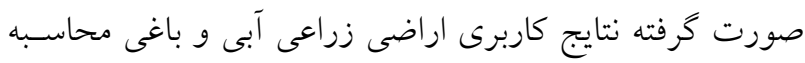

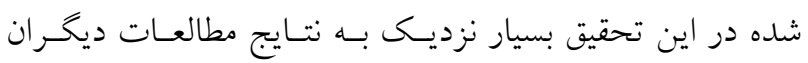
مىباشد. بررسى كاربرى اراضسى حاصـله از مـاهو اره مـوديس بـــاى

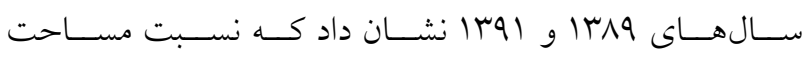

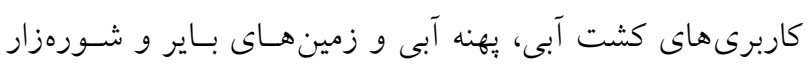

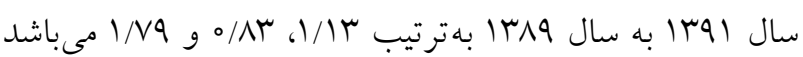


منابع مورد استفاده

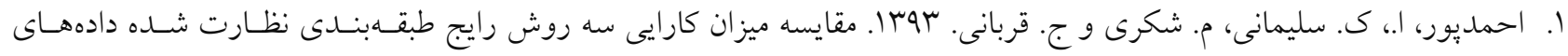

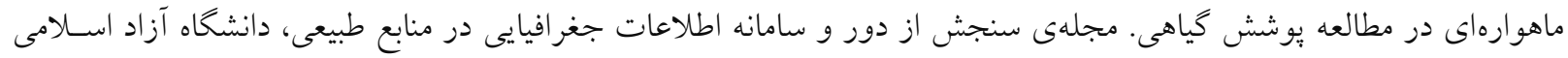

$. \wedge 9-V V: \varphi^{\mu}$

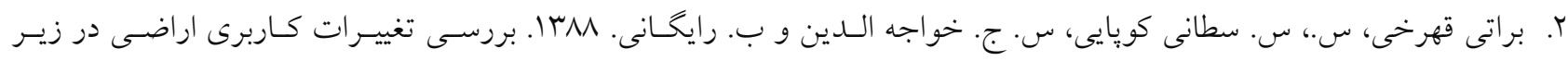

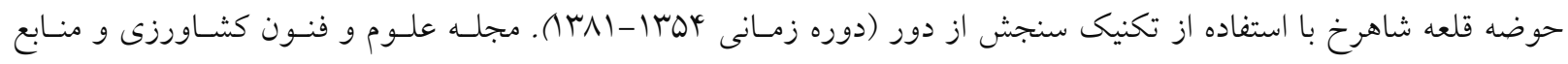

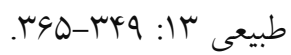

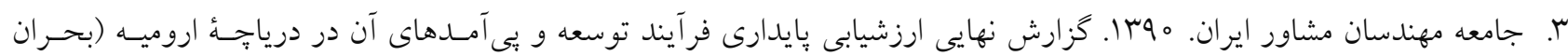

زيستمحيطى درياجِه اروميه).

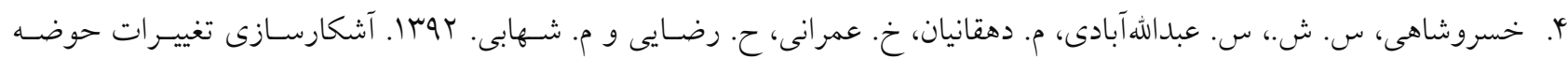

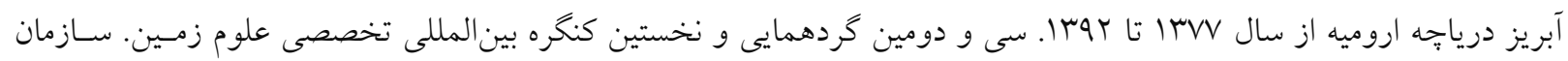

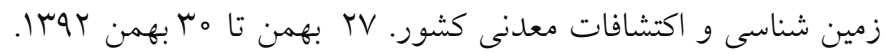

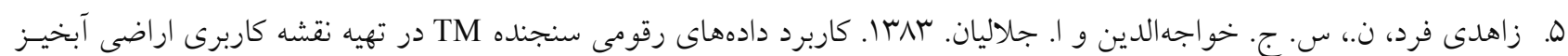

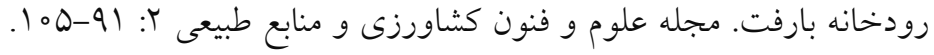

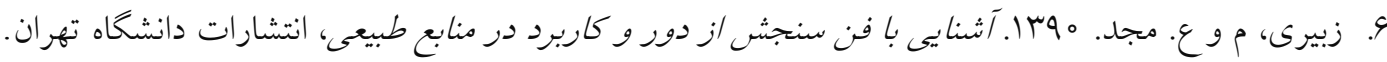

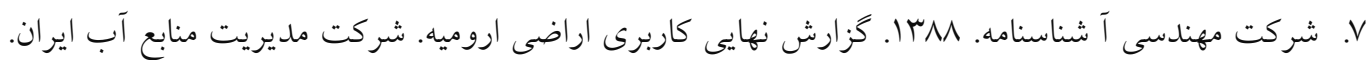

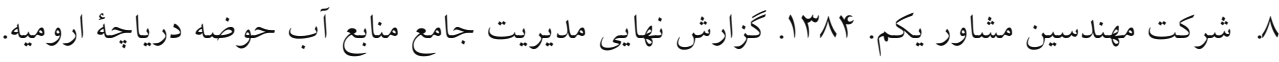

9. فتحيان، ف. هوץا. بررسى روند تغييرات كاربرى اراضى با استفاده از فن آورى سـنجش از دور و متغيرهـاى آب و هو اشناسى در

حوضه درياجةه اروميه. ياياننامه كارشناسى ارشد مهندسى آب، دانشكده كشاورزى، دانشخاه تربيت مدرس.

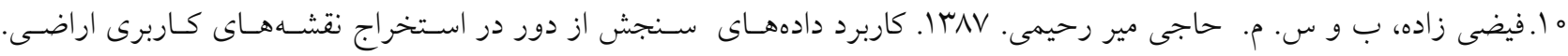

همايش زئوماتيك. سازمان نقشه بردارى كشور. تهران

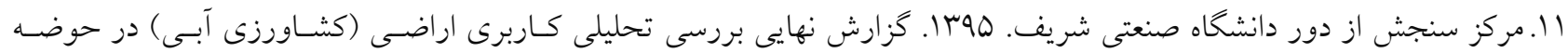

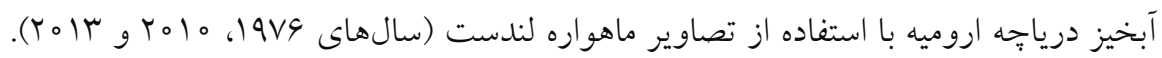

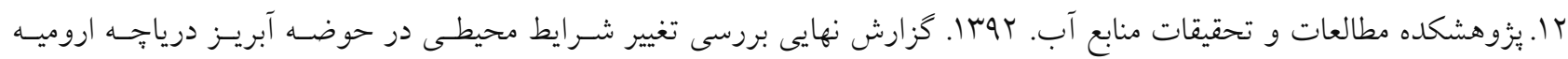

$$
\text { (كاربرى اراضى). }
$$

13. Ahmad, A. 2012. Analysis of maximum likelihood classification on multispectral data. J. Appl. Math. Sci. 6: 64256435.

14. Al-Ahmadi, F. S and A. S. Hames, 2007. Comparison of four classification methods to extract land use and land cover from raw satellite images for Some remote arid areas, Kingdom of Saudi Arabia. JKAU; J. Earth. Sci. 20:167-191.

15. Cohen, W. B., T. K. Maiersperger. Z. Yang. S. T. Gower. D. P. Turner. W. D. Ritts. M. Berterretche and S. W. Running. 2003. Comparisons of land cover and lai estimates derived from ETM+ and MODIS for four sites in North America: a quality assessment of 2000/2001 provisional MODIS products. J. Remote. Sens. Environ. 88: 233-255.

16. FAO/UNEP. 1999. Terminology for integrated resources planning and management, Food and Agriculture Organization/United Nations Environmental Program, Rome, Italy and Nairobi, Kenya.

17. Heumann, B.W. 2011. An object-based classification of mangroves using a hybrid decision tree-support vector machine approach. J. Remote. Sens. 3: 2440-2460. 
18. Kenduiywo, B. K., E. W. Nduati. C. N. Mundia and T. Korme. 2013. Land-cover mapping using landsat for sustainable greenhouse gas $(\mathrm{GHG})$ inventory development. $14^{\text {th }}$ GSDI. Addis Ababa.

19. Li, P., L. Jiang and Z. Feng. 2014. Cross- comparison of vegetation indices derived from landsat-7 enhanced thematic mapper plus (ETM+) and landsat-8 operational land imager (OLI) sensors. J. Remote. Sens. 6: $310-329$.

20. Liu, X., A. K. Skidmore and H. V. Oosten. 2002. Integration of classification methods for improvement of landcover map accuracy. J. Photogramm. Remote. Sens. 56: 257-267.

21. Manandhar, R., I. O. A. Odeh and T. Ancev. 2009. Improving the accuracy of land use and land cover classification of landsat data using post-classification enhancement. J. Remote. Sens. 1: 330-344.

22. Saadat, H., J. Adamowski. R. Bonnell. F. Sharif. M. Namdar and S. Ale-Ebrahim. 2011. Land use and land cover classification over a large area in Iran based on single date analysis of satellite imagery. J. Photogramm. Remote. Sens 66: 608-619.

23. Seto, K. C., C. E.Woodcock. C. Song. X. Huang. J. Lu and R. K. Kaufmann. 2002. Monitoring land-use change in the Pearl River Delta using landsat TM. Int. J. Remote. Sens. 23: 1985-2004.

24. Sousa, P. M. and J. Rocha. 2005. Land use/cover maps by RS and ancillary data integration in a GIS environment. global developments in environmental earth observation from space. $25^{\text {th }}$ EARSeL Symposium, Porto, Portugal. 


\title{
Analytical Study of Land Use Changes (Irrigated Agriculture) in the Watershed of Lake Urmia using Landsat Imagery
}

\author{
S. Youneszadeh Jalili ${ }^{1}$, M. Kamali ${ }^{* 1}$ and P. Daneshkar Arasteh ${ }^{2}$
}

(Received: June 07-2015 ; Accepted: May 11-2016)

DOI: 10.18869 /acadpub.jstnar.20.78.15

\begin{abstract}
Integrated management of watershed basins depends on deep knowledge of basic concepts such as the arrangement of lands and their uses. Location and distribution of agricultural land use help to balance water resources in the watershed basins. In this research with the help of satellite images of Landsat 5 and 8, and the method of maximum likelihood classification algorithm, land use types of water, barren areas and salt lands, and irrigated agriculture were studied in the Urmia watershed in the years 2010 and 2013.Then applications of modis images and product Urmia watershed land cover for years 2010 and 2012 were compared and finally modis and Landsat land covers in 2010 were compared. Results showed that the area of irrigated farmlands of Urmia basin has increased in the years between 2010 and 2013 ; while, the water zone has declined. Comparison between modis and landsat in 2010 showed that modis can estimate irrigated lands and water zone better than barren areas. The kappa coefficient for years 2010 and 2013 in Landsat images are $0 / 77$ and $0 / 87$, respectively.
\end{abstract}

Keywords: Irrigated agricultural lands, Land use, Maximum likelihood classification, Urmia watershed basin.

1. Remote Sensing Res. Center, Sharif Univ. of Technol., Tehran, Iran.

2. Faculty of Eng. and Technol., Imam Khomeini International Univ., Qazvin, Iran.

*: Corresponding Author, Email: meisamkamali_63@yahoo.com 